\title{
APLIKASI WEB UNTUK REKOMENDASI RESTORAN MENGGUNAKAN WEIGHTED PRODUCT
}

\author{
Santo Sinar Pandean, Seng Hansun \\ Program Studi Informatika, Universitas Multimedia Nusantara, Tangerang \\ Email: santo.sinar@student.umn.ac.id, hansun@umn.ac.id
}

(Naskah masuk: 19 Januari 2018, diterima untuk diterbitkan: 18 Februari 2018)

\begin{abstract}
Abstrak
Kebutuhan akan makanan merupakan hal pokok dalam kehidupan manusia. Tidak sedikit pula masyarakat yang melakukan wisata kuliner untuk memenuhi kebutuhan makanan bagi kehidupan. Tentunya, hal tersebut menyebabkan suatu keadaan dimana masyarakat membutuhkan suatu informasi mengenai restoran yang dapat menjadi pertimbangan untuk dikunjungi. Hal inilah yang menjadi latar belakang untuk membuat sistem rekomendasi restoran. Tujuan penelitian ini adalah merancang dan membangun sistem rekomendasi restoran berbasis web dengan menggunakan metode Weighted Product. Berdasarkan skenario uji coba, dapat disimpulkan bahwa algoritma Weighted Product telah berjalan dengan benar pada aplikasi yang dibangun. Tingkat kepuasan pengguna berdasarkan hasil kuesioner yang dilakukan terhadap 30 responden secara langsung adalah sebesar $78,55 \%$ yang mengindikasikan bahwa pengguna merasa puas dengan aplikasi yang dibangun. Kuesioner yang digunakan juga disimpulkan bersifat reliabel dengan hasil perhitungan menggunakan Cronbach Alpha sebesar 0,792 .
\end{abstract}

Kata kunci: sistem rekomendasi, Weighted Product, Cronbach Alpha, kuesioner, reliabilitas

\section{RESTAURANT RECOMMENDATION WEB APPLICATION USING WEIGHTED PRODUCT}

\begin{abstract}
The need of food is essential thing in our life. Not a few people who do culinary tours to meet the needs of food for life. Of course, it causes a situation where the community needs an information about the restaurant that can be considered to be visited. This is the background for making restaurant recommendation system. The purpose of this study is to design and build web based restaurant recommendation system by using method of weighted product. Based on a trial scenario, it can be concluded that the weighted product algorithm has been running correctly on the bult application. The level of user satisfaction based on the results of questionnaires conducted on 30 respondents directly is equal to $78.55 \%$ indicating that users are satisfied with the application built. The questionnaire conducted is also reliable since its Cronbach Alpha value is 0.792 .
\end{abstract}

Keywords: recommendation system, Weighted Product, Cronbach Alpha, questionnaire, reliability

\section{PENDAHULUAN}

Kehidupan manusia tidak bisa terlepas dari makanan sebagai suatu hal yang wajib terpenuhi untuk dapat bertahan hidup. Teori estetika menjelaskan fenomena estetik yang dapat membantu dalam memahami pengalaman seni dan sesuatu yang berada di lingkungan sekitar menjadi lebih jernih (Berleant, 2004). Berdasarkan pernyataan tersebut, kini dapat dipahami bahwa pada zaman sekarang ini, makanan bukanlah semata-mata hanya untuk memenuhi kebutuhan hidup mausia, melainkan makanan sudah berkembang menjadi sebuah seni. Berdasarkan survei yang dilakukan kementrian Kesehatan RI pada tahun 2014, rata-rata pengeluaran per kapita sebulan yang digunakan untuk memenuhi kebutuhan makanan adalah sebanyak 50,04\%. Hal ini lebih tinggi, dibandingkan dengan pengeluaran untuk non makanan sebesar 49,96\% (Kementerian Kesehatan Republik Indonesia, 2016). Oleh karena itu, makanan merupakan hal yang sangat erat kaitannya dengan kehidupan manusia. Pada zaman seperti sekarang ini, usaha restoran menjadi suatu usaha yang menjanjikan untuk mendapatkan keuntungan yang cukup menggiurkan. Di kota Jakarta saja perkembangan usaha restoran kelas menengah hingga kelas atas mencapai $250 \%$ dalam 5 tahun terakhir (Lukman, 2014). Oleh karenanya, seperti yang diketahui, banyak sekali restoran yang dibuka, sehingga berbagai jenis restoran dapat ditemukan dengan mudah. Dalam dunia kuliner, muncul sebuah tren baru khususnya pada 
masyarakat perkotaan untuk makan di luar rumah atau biasa disebut dengan wisata kuliner (Nugroho \& Ferdiana, 2014).

Jika dikaitkan dengan manfaat teknologi, pada zaman sekarang ini, sangat mudah sekali bagi setiap orang untuk dapat melakukan pencarian mengenai informasi suatu restoran. Dengan banyaknya sumber informasi mengenai restoran tersebut, hal itu akan membantu masyarakat untuk mendapatkan informasi mengenai suatu restoran. Akan tetapi, dengan banyaknya informasi tersebut, justru juga dapat membuat masyarakat kebingungan untuk memilih restoran mana yang tepat untuk dikunjungi. Akibatnya, dalam memilih suatu restoran, seringkali dibutuhkan waktu yang lama, sehingga ini bukanlah suatu hal yang efektif. Oleh karena itu, sistem rekomendasi restoran dapat menjadi suatu solusi yang tepat bagi setiap orang dengan memberikan berbagai macam pilihan restoran yang terbaik untuk dikunjungi (Nugroho \& Ferdiana, 2014).

Sistem rekomendasi merupakan salah satu cabang dari sistem pendukung keputusan, yang tidak lain merupakan suatu model aplikasi terhadap keinginan dan keadaan pengguna (Petra \& Hansun, 2016). Selama beberapa dekade terakhir, sistem rekomendasi telah banyak diterapkan dengan berbagai pendekatan dan teknik baru, baik di dunia industri maupun di dunia akademis (Parwita \& Winarko, 2015). Konsep sistem rekomendasi telah digunakan secara luas oleh hampir semua area bisnis, dimana seorang user memerlukan informasi untuk membuat suatu keputusan, sebagaimana yang dapat dilihat pada makalah karya Lu, dkk. (2013).

Dalam merancang dan membangun suatu sistem rekomendasi terdapat beberapa metode atau pendekatan yang dapat digunakan, namun secara garis besar terdapat dua pendekatan yang dapat digunakan, yakni Collaborative-filtering dimana rekomendasi dilakukan berdasarkan kebiasaan dari pengguna lainnya dan Content-based filtering dimana rekomendasi dilakukan berdasarkan tingkat kesamaan antara item yang sebelumnya pernah diberi like dengan item lain oleh pengguna itu sendiri (Sumarlin, dkk., 2016). Metode atau pendekatan yang dipilih pada sistem rekomendasi bergantung pada permasalahan yang akan diselesaikan. Teknik rekomendasi yang berbedabeda dapat digunakan untuk aplikasi yang berbeda berdasarkan pada tujuan dan objektif dari aplikasi itu sendiri. Bahkan untuk satu sistem yang sama, dapat diterapkan lebih dari satu metode rekomendasi guna memberikan hasil rekomendasi terbaik bagi pengguna sistem, seperti yang dapat dijumpai di Netflix (Gomez-Uribe \& Hunt, 2016).

Metode yang digunakan dalam membangun aplikasi ini adalah metode collaborative filtering. Metode Weighted Product (WP) digunakan untuk mendukung cara kerja metode collaborative filtering tersebut. Aplikasi yang akan dibuat nantinya akan bergantung pada opini pengguna lainnya yang diterima oleh aplikasi dalam bentuk rating. Alasan pemilihan metode Weighted Product karena metode Weighted Product menentukan nilai bobot untuk setiap atribut, kemudian dilanjutkan dengan proses perangkingan yang akan menyeleksi alternatif terbaik dari sejumlah alternatif yang ada. Selain itu metode WP juga dapat diterapkan dalam kasuskasus yang memiliki unsur subjektivitas yang tinggi (Ahmadi \& Wiyanti, 2014).

Sebelum penelitian ini, penelitian mengenai aplikasi rekomendasi restoran sudah pernah dilakukan dengan judul Aplikasi Rekomendasi Tempat Makan Menggunakan Algoritma Slope One pada Platform Android (Pratama \& Hansun, 2017). Pada penelitian ini, data restoran yang direkomendasikan didapat melalui Google Places API. Selain itu, menurut Komunitas Wisata Kuliner Tasik (2015), terdapat lima kriteria utama dalam melakukan penilaian kualitas suatu tempat makan, yaitu rasa makanan, kebersihan, harga, pelayanan dan kualitas tempat, yang akan digunakan dalam penelitian yang dilakukan.

\section{WEIGHTED PRODUCT (WP)}

Metode WP merupakan salah satu metode pembobotan, dimana perkalian digunakan untuk menghubungkan rating atribut, dan rating setiap atribut harus dipangkatkan terlebih dahulu dengan bobot atribut yang bersangkutan. Metode WP paling banyak digunakan untuk menyelesaikan masalah Multiple Attribute Decision Making (MADM). $M A D M$ merupakan suatu metode yang digunakan untuk mencari alternatif yang paling baik dari sejumlah alternatif yang ada berdasarkan kriteria tertentu (Burhanudin, 2013).

Menurut Jayanti (2014), preferensi untuk alternatif $\mathrm{A}_{\mathrm{i}}$ diberikan sebagai berikut.

$S_{i}=\prod_{j=1}^{n}\left(x_{i j}\right)^{w_{j}}$

Keterangan:

$\mathrm{S}=$ Preferensi alternatif dianalogikan sebagai vektor $\mathrm{S}$

$x_{i j}=$ Nilai variabel dari alternatif pada setiap atribut

$w_{j}=$ Nilai bobot kriteria

n = Banyaknya kriteria

$\mathrm{i}=$ Nilai alternatif

$\mathrm{j} \quad=$ Nilai kriteria

Dengan $\sum w_{j}=1$, sedangkan $w_{j}$ adalah pangkat bernilai positif untuk atribut keuntungan, dan bernilai negatif untuk atribut biaya.

Preferensi relatif dari setiap alternatif diberikan sebagai berikut.

$V_{i}=\frac{\prod_{j=1}^{n}\left(x_{i j}\right)^{w_{j}}}{\prod_{j=1}^{n}\left(x_{j}\right)^{w_{j}}}$

Keterangan: 
$\mathrm{V}=$ Preferensi relatif dari setiap alternatif dianalogikan vektor $\mathrm{V}$

$x_{i j}=$ Nilai variabel dari alternatif pada setiap atribut

$w_{j}=$ Nilai bobot kriteria

$\mathrm{n}=$ Banyaknya kriteria

$\mathrm{i}=$ Nilai alternatif

$\mathrm{j}=$ Nilai kriteria

* = Banyaknya kriteria yang telah dinilai pada vektor $\mathrm{S}$

Langkah-langkah menggunakan metode ini adalah sebagai berikut (Jayanti, 2014):

a. Menentukan kriteria-kriteria yang akan dijadikan acuan dalam pengambilan keputusan.

b. Menentukan rating kecocokan setiap alternatif pada setiap kriteria.

c. Menentukan bobot preferensi tiap kriteria.

d. Mengalikan seluruh atribut bagi sebuah alternatif dengan bobot sebagai pangkat positif untuk atribut keuntungan dan bobot berpangkat negatif untuk atribut biaya.

e. Hasil perkalian tersebut dijumlahkan untuk menghasilkan nilai $\mathrm{V}$ untuk setiap alternatif.

f. Mencari nilai alternatif dengan melakukan langkah yang sama seperti pada langkah satu, hanya saja menggunakan nilai tertinggi untuk setiap atribut manfaat dan nilai terendah untuk atribut biaya.

g. Membagi nilai $\mathrm{V}$ bagi setiap alternatif dengan nilai standar $\left(\mathrm{V}\left(\mathrm{A}^{*}\right)\right)$ yang menghasilkan $\mathrm{R}$.

h. Mencari nilai alternatif ideal.

Dalam menentukan bobot untuk setiap item dalam metode Weighted Product, harus mencerminkan jarak dan prioritas setiap kriteria dengan tepat. Setelah menentukan bobot preferensi maka akan dilakukan perbaikan bobot terlebih dahulu, sehingga total bobot $\sum w_{j}=1$. Perbaikan bobot dilakukan dengan cara sebagai berikut.

$W_{j}=\frac{w_{j}}{\sum w_{j}}$

Keterangan:

$w_{j}=$ Bobot preferensi sebelumnya

\section{METODOLOGI DAN PERANCANGAN}

\subsection{Metodologi Penelitian}

Metodologi penelitian yang digunakan dalam penelitian ini adalah sebagai berikut.

\section{Studi Literatur}

Pada tahap ini, dicari referensi mengenai teoriteori pendukung penelitian, seperti Weighted Product, Application Programming Interface (API), sistem rekomendasi. Referensi dapat dicari melalui sumber buku, jurnal, artikel, sampai internet. Tujuan dari studi literatur adalah sebagai dasar teori untuk memperkuat penyelesaian masalah pada penelitian.

2. Pengumpulan Data

Pada tahap ini, dikumpulkan data restoran yang didapatkan dari Zomato API, dan urutan prioritas dari kriteria yang menjadi faktor pengaruh hasil rekomendasi yang didapatkan melalui kuesioner.

3. Perancangan Aplikasi

Pada tahap ini, dilakukan perancangan aplikasi yang terdiri dari pembuatan Flowchart algoritma, Data Flow Diagram, Entity Relationship Diagram, struktur tabel, dan rancangan antarmuka yang berfungsi untuk memudahkan proses pembangunan aplikasi agar sesuai dengan rencana.

4. Pembuatan Program

Pada tahap ini, dilakukan proses pembuatan program sesuai dengan kebutuhan program yang telah ditentukan pada tahap perancangan aplikasi. Pembuatan program meliputi tampilan antarmuka pada aplikasi berbasis web, database, koneksi terhadap API Zomato, dan pembuatan kode program secara keseluruhan.

5. Uji Coba dan Perbaikan Program

Proses pengujian sistem dilakukan ketika aplikasi telah selesai dibangun. Pada tahap ini, akan dilakukan dua jenis pengujian, yaitu uji skenario dan uji kepuasan pengguna. Uji skenario berfungsi untuk memastikan bahwa algoritma Weighted Product dapat berjalan dengan benar pada aplikasi, sedangkan uji kepuasan pengguna dilakukan dengan menggunakan kuesioner untuk mengetahui tingkat kepuasan pengguna mengenai aplikasi. Kuesioner akan disebar ke minimal 30 responden dan maksimal 500 responden (Sekaran, 2006). Untuk penentuan kesimpulan apakah pengguna puas atau tidak dalam menggunakan aplikasi, akan digunakan skala likert dan juga cronbach alpha untuk menentukan hasilnya.

\subsection{Perancangan Aplikasi}




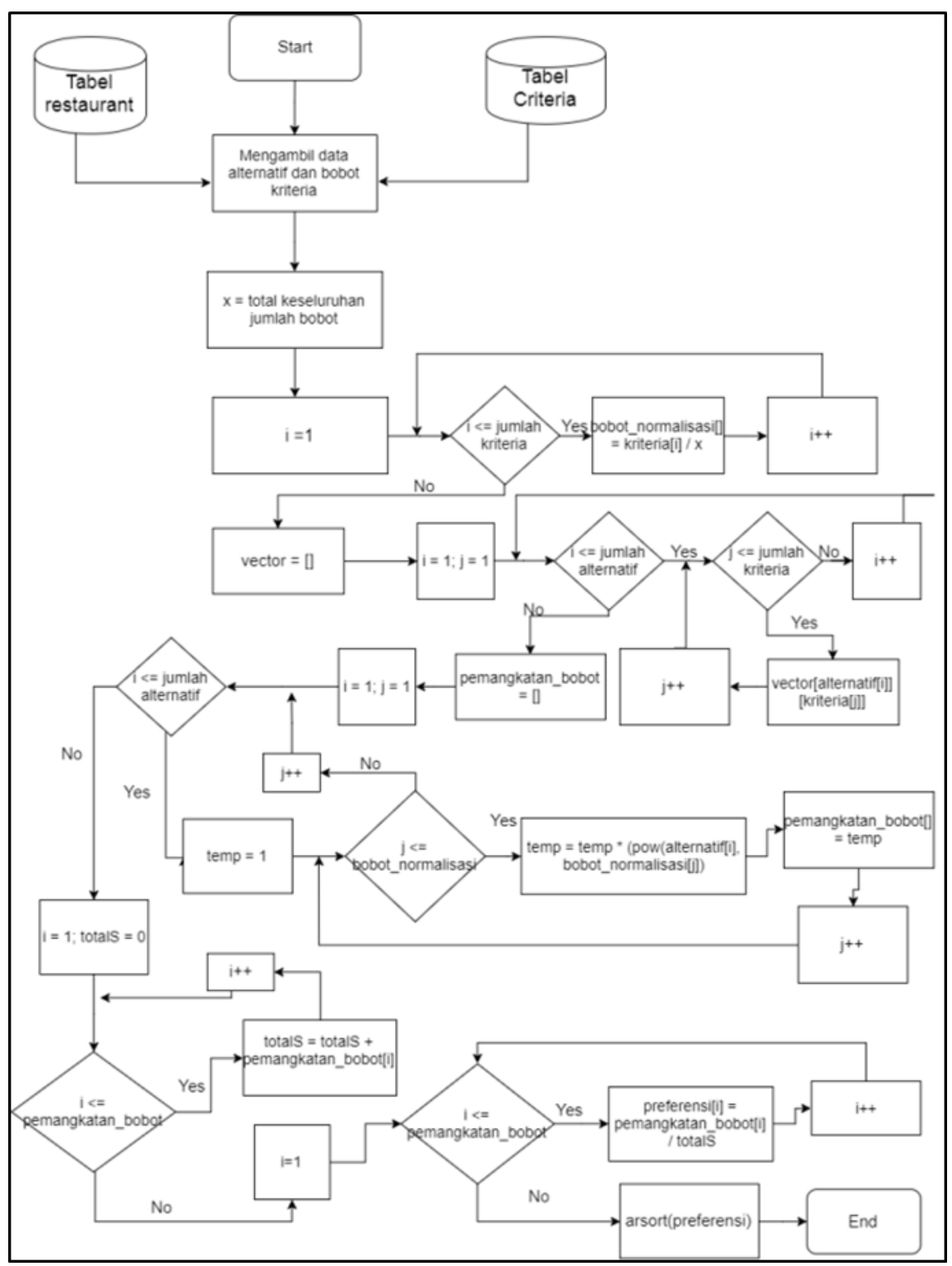

Gambar 1. Flowchart Algoritma Weighted Product

Gambar 1 merupakan flowchart dari algoritma weighted product, dimana proses dimulai dengan mengambil data alternatif dari tabel restaurant, dan bobot kriteria dari tabel criteria. Kemudian, akan dilakukan proses perbaikan bobot dengan melakukan looping sebanyak jumlah kriteria. Dalam setiap pengulangan akan dilakukan proses pembagian antara nilai bobot kriteria dengan total bobot keseluruhan dan disimpan dalam sebuah array. Selanjutnya akan dibentuk matriks keputusan yang berupa array dua dimensi, dimana dimensi pertama berisi nama alternatif dan dimensi kedua berisi nama kriteria. Kemudian akan dilakukan proses pemangkatan alternatif dengan bobot kriteria. Pemangkatan dilakukan dengan melakukan nested looping, dimana data alternatif yang akan di-looping pertama, sedangkan data yang akan di-looping selanjutnya adalah array yang menyimpan bobot kriteria yang telah dinormalisasi. Pada proses ini, akan dilakukan pemangkatan antara nilai alternatif kriteria dengan bobot kriteria yang akan disimpan dalam sebuah array. Selanjutnya akan dilakukan proses perhitungan preferensi untuk setiap alternatif dengan cara melakukan looping array hasil pemangkatan dan membagi setiap nilai hasil pemangkatan dengan total pemangkatan keseluruhan, kemudian hasilnya akan disimpan dalam array preferensi yang kemudian akan diurutkan dari yang terbesar hingga terkecil. 


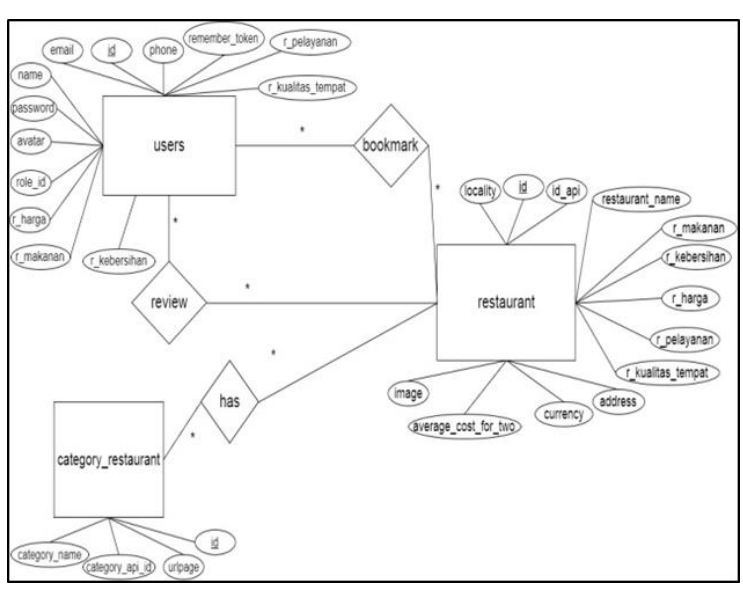

Gambar 2. Entity Relationship Diagram

Seorang pengguna atau users dapat melakukan bookmark terhadap lebih dari restoran, dan juga satu restoran dapat dijadikan bookmark oleh lebih dari satu pengguna. Selain melakukan bookmark, seorang pengguna dapat memberikan review atau rating terhadap lebih dari satu restoran, dan satu restoran dapat menerima review lebih dari satu pengguna. Oleh karena itu terjadi hubungan many to many antara entitas users dan juga entitas restaurant yang disebabkan oleh proses bookmark dan juga proses review.

Pada aplikasi sistem rekomendasi restoran yang dibangun, terdapat beberapa kategori restoran, sehingga terbentuklah entitas category_restaurant. Satu kategori restoran dapat memiliki lebih dari satu restoran dan satu restoran dapat berada di lebih dari satu kategori restoran.

\section{IMPLEMENTASI DAN UJICOBA}

\subsection{Hasil Implementasi}

Dalam pembuatan aplikasi sistem rekomendasi restoran berbasis web, digunakan bahasa pemrograman PHP versi 5.6.24 dengan MySQL sebagai basis datanya, sedangkan Apache digunakan sebagai web server. Implementasi dimulai dengan membuat basis data yang terdiri dari sembilan tabel sesuai dengan perancangan yang dilakukan. Tabel tersebut antara lain adalah tabel users, tabel bookmark, tabel category_restaurant, tabel contact_us, tabel criteria, tabel list_category_restaurant, tabel password_resets, tabel rating, tabel restaurant.

Setelah tabel terbentuk, dibuatlah akun developer pada Zomato untuk dapat mengakses API yang disediakan oleh Zomato. Ketika akun terbentuk, maka akan didapatkan API key dan secret key yang digunakan untuk pengambilan data ke Zomato API. Kemudian dilakukan pemrograman untuk membangun halaman admin. Halaman admin memiliki fitur CRUD untuk setiap tabel yang telah terbentuk. Selain itu, dilakukan juga pemrograman untuk proses sinkronisasi data restoran serta kategori restoran dari Zomato API ke basis data lokal.

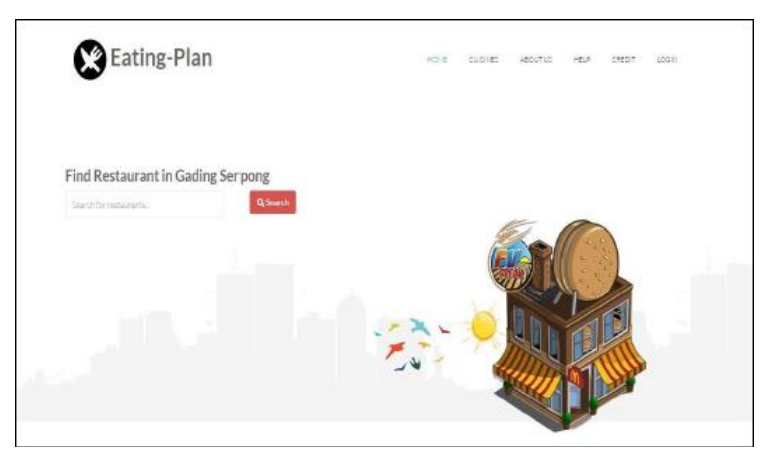

Gambar 3. Implementasi Halaman Home Pengguna

Gambar 3 merupakan tampilan untuk halaman Home bagian slider pada aplikasi sistem rekomendasi yang dibangun. Pada sebelah kiri slider, terdapat sebuah form yang dapat digunakan untuk mencari suatu restoran. Setiap halaman pengguna pada aplikasi sistem rekomendasi, terdapat header dan footer. Pada bagian header, terdapat beberapa menu yang digunakan sebagai navigasi untuk berpindah ke halaman lain. Kemudian untuk bagian footer, terdapat form yang berguna untuk mengirim pesan yang berhubungan dengan aplikasi sistem rekomendasi yang dibangun.

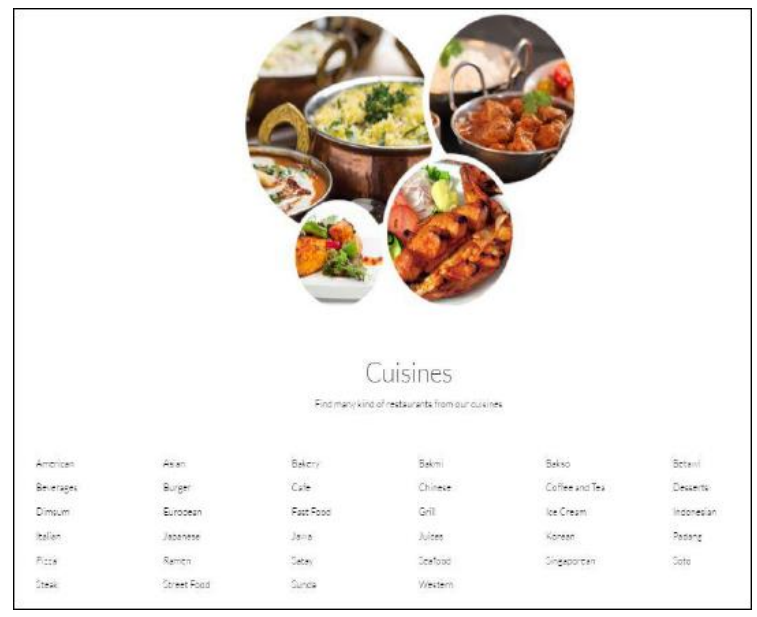

Gambar 4. Implementasi Daftar Kategori Restoran

Selanjutnya, pada bagian bawah halaman Home, terdapat daftar kategori restoran sebagaimana yang ditunjukkan pada Gambar 4. Ketika pengguna memilih salah satu kategori restoran, maka pengguna akan diarahkan ke halaman Rekomendasi Restoran. Rekomendasi restoran yang diberikan merupakan hasil dari perhitungan dengan menggunakan algoritma weighted product. Daftar restoran yang direkomendasikan merupakan restoran yang sesuai dengan jenis kategori yang dipilih oleh pengguna. Pengguna juga dapat langsung mengakses halaman ini dengan mengklik "cuisines" yang terdapat pada bagian menu navigasi. 


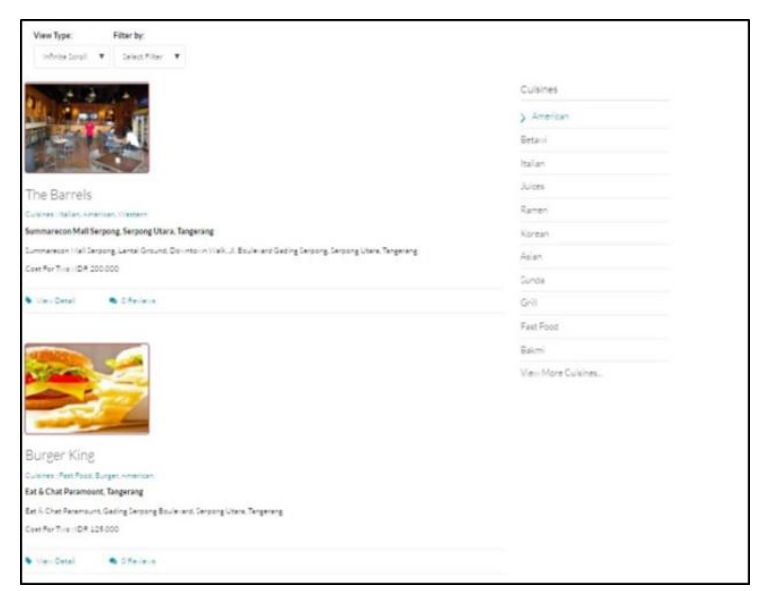

Gambar 5. Implementasi Halaman List Rekomendasi

Gambar 5 merupakan tampilan untuk halaman Rekomendasi Restoran menggunakan algoritma weighted product berdasarkan kategori restoran yang dipilih oleh pengguna. Pengguna dapat melihat sedikit informasi mengenai restoran. Untuk masuk ke halaman detail restoran, pengguna perlu untuk mengklik gambar atau nama dari restoran. Untuk bagian sebelah kanan, terdapat navigasi yang dapat mengarahkan pengguna untuk melihat daftar rekomendasi untuk jenis kategori restoran lainnya.

\subsection{Skenario Uji Coba Weighted Product}

Skenario uji coba yang dilakukan adalah dengan melakukan perhitungan manual menggunakan metode weighted product dengan menggunakan kategori seafood yang terdiri dari 13 data restoran (pada sistem sebenarnya yang diimplementasikan jumlah kategori dan data bergantung pada data yang tersedia di Zomato API). Berikut merupakan data restoran yang terdapat pada kategori seafood dan digunakan pada uji coba ini.

Tabel 1. Data Restoran Alternatif

\begin{tabular}{ccccccc}
\hline Alternatif & C1 & C2 & C3 & C4 & C5 \\
\hline Chicken Village & 3.15 & 3.65 & 3.15 & 3.65 & 3.65 \\
Tha San & 1.5 & 1.5 & 1.5 & 2 & 1.5 \\
Rasane & 3.35 & 4.35 & 3.35 & 3.85 & 3.85 \\
$\begin{array}{c}\text { Hong Chu Shao } \\
\text { Kao }\end{array}$ & 3 & 3 & 3.5 & 3.5 & 3.5 \\
\hline
\end{tabular}

Setelah mendapatkan alternatif restoran yang akan direkomendasikan, kemudian sistem akan mengambil data kriteria yang akan digunakan untuk perhitungan bobot pada algoritma weighted product. Berikut merupakan data kriteria restoran beserta poin responden untuk masing-masing kriteria yang didapatkan melalui kuesioner awal.

Tabel 2. Data Kriteria Perbandingan

\begin{tabular}{lcc}
\hline No & Nama Kriteria & Poin Responden \\
\hline C1 & Makanan & 311 \\
C2 & Kebersihan & 306 \\
C3 & Harga & 299 \\
C4 & Pelayanan & 289 \\
C5 & Kualitas Tempat & 259 \\
\hline
\end{tabular}

Proses perhitungan menggunakan weighted product dimulai dengan perbaikan bobot terhadap kriteria-kriteria yang ada yaitu sebagai berikut.

$$
\begin{aligned}
& \mathrm{W}_{1}=\frac{311}{311+306+299+289+259}=0.212431694 \\
& \mathrm{~W}_{2}=\frac{306}{311+306+299+289+259}=0.209016393 \\
& \mathrm{~W}_{3}=\frac{299}{311+306+299+289+259}=0.204234972 \\
& \mathrm{~W}_{4}=\frac{289}{311+306+299+289+259}=0.197404371 \\
& \mathrm{~W}_{5}=\frac{259}{311+306+299+289+259}=0.176791808
\end{aligned}
$$

Dengan mengikuti langkah-langkah metode weighted product maka didapatkan nilai preferensi untuk setiap alternatif sebagai berikut.

\begin{tabular}{lll}
\multicolumn{3}{c}{ Tabel 3. Hasil Perhitungan Metode Weighted Product } \\
\hline Nama Restoran & Nilai S & Nilai V \\
\hline Rasane & 3.726495135 & 0.093847848 \\
Chicken Village & 3.432145295 & 0.086434958 \\
Hong Chu Shao Kao & 3.335075215 & 0.08399035 \\
Tha San & 1.587572058 & 0.039981327 \\
\hline
\end{tabular}

Tabel 3 menunjukkan urutan beserta nilai akhir perhitungan WP pada setiap alternatif. Perankingan dilakukan berdasarkan nilai preferensi untuk setiap alternatif yang diurutkan dari nilai terbesar hingga terkecil.

\subsection{Uji Kepuasan Pengguna dan Reliabilitas Kuesioner}

Survei kepuasan dilakukan dengan melakukan pengisian kuesioner terhadap 30 responden atau pengguna aplikasi secara langsung. Target responden ditujukan pada para penikmat kuliner terutama di wilayah Gading Serpong yang dapat mengakses aplikasi melalui smartphone. Kuesioner yang diberikan berisi tujuh pernyataan yang berkaitan dengan sistem yang telah dibuat dengan menggunakan konsep End-User Computing Satisfaction (EUCS) yang diusulkan oleh Doll dan Torkazdeh (1988). Tabel 4 memperlihatkan data hasil kuesioner yang telah dilakukan.

Tabel 4. Rancangan Analisis Komputasi

\begin{tabular}{lrrrrr}
\hline & \multicolumn{5}{c}{ Jawaban } \\
\cline { 2 - 7 } & SS & S & N & TS & STS \\
$\begin{array}{l}\text { Aplikasi Eating Plan mudah } \\
\text { untuk digunakan (user-friendly) }\end{array}$ & 8 & 20 & 2 & - & - \\
$\begin{array}{l}\text { Aplikasi Eating Plan memiliki } \\
\text { rancangan antarmuka yang }\end{array}$ & 6 & 18 & 5 & 1 & - \\
menarik & & & & & \\
$\begin{array}{l}\text { Eating Plan memberikan } \\
\text { informasi restoran secara } \\
\text { lengkap }\end{array}$ & 4 & 11 & 15 & - & - \\
$\begin{array}{l}\text { Eating Plan menyediakan hasil } \\
\text { rekomendasi restoran yang } \\
\text { memuaskan }\end{array}$ & 7 & 13 & 10 & - & - \\
$\begin{array}{l}\text { Eating Plan mampu menyajikan } \\
\text { hasil rekomendasi restoran } \\
\text { secara cepat }\end{array}$ & 4 & 21 & 4 & 1 & - \\
$\begin{array}{l}\text { Eating Plan mampu menghemat } \\
\text { waktu pengguna dalam }\end{array}$ & 5 & 19 & 5 & 1 & - \\
\hline
\end{tabular}




\begin{tabular}{|c|c|c|c|c|c|}
\hline $\begin{array}{l}\text { Eating Plan membantu dalam } \\
\text { menentukan pilihan restoran } \\
\text { yang terdapat di Gading } \\
\text { Serpong }\end{array}$ & 6 & 17 & 7 & - & - \\
\hline
\end{tabular}

Setelah perhitungan persentase kepuasan pengguna untuk setiap aspek yang merupakan bagian dari EUCS, maka dilakukan perhitungan persentase kepuasan pengguna secara keseluruhan dengan menghitung rata-rata persentase dari setiap aspek yang ada. Hasilnya sebesar 78,55\% responden merasa puas dengan aplikasi rekomendasi restoran yang dibangun, hal tersebut mengindikasikan bahwa responden merasa puas terhadap aplikasi rekomendasi restoran.

Uji realibilitas kuesioner dilakukan untuk mengukur keandalan hasil dari suatu kuesioner. Untuk mengukur realibilitas kuesioner pada penelitian ini, digunakan Cronbach Alpha. Setelah melakukan perhitungan menggunakan Cronbach Alpha didapatkan koefisien alpha sebesar 0,792. Dengan demikian, dapat disimpulkan bahwa hasil kuesioner pada penelitian ini bersifat reliabel dan dapat dipercaya.

\section{SIMPULAN DAN SARAN}

Berdasarkan hasil penelitian yang telah dilakukan, maka dapat diambil kesimpulan bahwa penelitian ini telah berhasil merancang dan membangun sistem rekomendasi restoran berbasis web dengan menggunakan metode weighted product. Aplikasi sistem rekomendasi yang dibangun memiliki fitur menampilkan daftar rekomendasi restoran berdasarkan kategori restoran yang dipilih dengan menggunakan algoritma weighted product, menampilkan daftar restoran favorit, pemberian rating oleh pengguna, serta bookmark untuk setiap restoran. Skenario uji coba dilakukan dengan cara membandingkan hasil perhitungan manual dan hasil yang diberikan oleh sistem. Hasil uji coba tersebut menunjukkan bahwa hasil rekomendasi yang diberikan oleh sistem telah sesuai dengan perhitungan manual. Selanjutnya dilakukan uji coba kepuasan pengguna untuk mengukur tingkat kepuasan pengguna terhadap aplikasi sistem rekomendasi yang dibangun. Uji kepuasan pengguna dilakukan dengan menyebarkan kuesioner kepada 30 responden secara langsung, dan didapatkan persentase kepuasan pengguna sebesar 78,55\% yang mengindikasikan bahwa pengguna merasa puas dengan aplikasi. Kemudian dilakukan uji coba realibilitas terhadap kuesioner dengan menggunakan rumus Cronbach Alpha. Uji coba realibilitas menghasilkan nilai sebesar 0,792 , yang menandakan bahwa kuesioner yang dilakukan bersifat reliabel.

Dalam pengembangan penelitian selanjutnya dapat digunakan metode AHP sebagai alternatif algoritma dalam menghasilkan rekomendasi restoran, karena AHP mempunyai kemampuan untuk memecahkan masalah yang bersifat multi obyek dan multi kriteria yang berdasar pada perbandingan preferensi tiap elemen dalam hierarki. Selain itu, perluasan database dan ruang lingkup restoran dapat dilakukan karena memengaruhi hasil rekomendasi aplikasi. Beberapa fitur tambahan, seperti maps dan online reservation juga dapat dipertimbangkan dalam penelitian selanjutnya.

\section{DAFTAR PUSTAKA}

AHMADI, A. \& WIYANTI, D.T., 2014. Implementasi Weighted Product (WP) dalam Penentuan Penerima Bantuan Langsung Masyarakat PNPM Mandiri Pedesaan. Prosiding Seminar Nasional Aplikasi Teknologi Informasi (SNATI), p.19-22. [online]. Tersedia di: <http://journal.uii.ac.id/index.php/Snati/arti cle/view/3231/2923> [Diakses 23 November 2017]

BERLEANT, A., 2004. Re-thinking Aesthetics: Rogue Essays on Aesthetics and the Arts. Burlington, USA: Ashgate Publishing Company.

BURHANUDIN, M., 2013. Metode Sistem Pendukung Keputusan Weighted Product. [online]. Tersedia di: <http://burhanudin.web.id/programing/met ode-sistem-pendukung-keputusanweighted-product> [Diakses 22 Desember 2017]

DOLL, W.J. \& TORKAZDEH, G., 1988. The Measurement of End User Computing Satisfaction. MIS Quarterly, 12(2), p.159174.

GOMEZ-URIBE, C.A. \& HUNT, N., 2016. The Netflix Recommender System: Algorithms, Business Value, and Innovation. ACM Transaction on Management Information Systems, 6(4), p.13:1-13:19.

JAYANTI, L.D., 2014. Implementasi Metode Weighted Product pada Sistem Pendukung Keputusan Pemberian Kredit pada BPR BKK KARANGANYAR Kab. Pekalongan. Thesis. Semarang: Universitas Dian Nuswantoro.

KEMENTERIAN KESEHATAN REPUBLIK INDONESIA, 2016. Persentase Pengeluaran Rata-rata per Kapita Sebulan Menurut Kelompok Barang Tahun 2014. [online]. Tersedia di: <http://www.depkes.go.id/resources/downl oad/pusdatin/profil-kesehatanindonesia/profil-kesehatan-Indonesia2015.pdf> [Diakses 12 Desember 2017]

KOMUNITAS WISATA KULINER TASIK (KWKT), 2015. Panduan Menilai Tempat Kuliner. [online]. Tersedia di: 
<https://www.facebook.com/komunitaswis atakulinertasik/posts/916199391733827> [Diakses 30 November 2017]

LU, J., SHAMBOUR, Q., XU, Y., LIN, Q., \& ZHANG, G., 2013. A Web-Based Personalized Business Partner Recommendation System using Fuzzy Semantic Techniques. Computational Intelligence, 29(1), p.37-69.

LUKMAN, E., 2014. Qraved: Jakarta Diners Spent $\$ 1.5$ Billion on Dining Out in 2013 (Infographic). [online]. Tersedia di: <https://www.techinasia.com/qravedjakarta-diners-spent-15-billion-dining2013-infographic> [Diakses 13 Februari 2018]

NUGROHO R.A., \& FERDIANA, R., 2014. Teknik Pemberian Rekomendasi Menu Makanan dengan pendekatan Contextual Model dan Multi Criteria Decision Making. Prosiding Conference on Information Technology and Electrical Engineering (CITEE 2014), p.8894.

PARWITA, W.G.S. \& WINARKO, E., 2015. Hybrid Recommendation System Memanfaatkan Penggalian Frequent Itemset dan Perbandingan Keyword. IJCCS (Indonesian J. Comput. Cybern. Syst.), [ejournal] 9(2), p.167-176. Tersedia melalui: $<$ https://jurnal.ugm.ac.id/ijccs/article/view/ 7545/5868> [Diakses 12 Januari 2018]
PETRA, Y. \& HANSUN, S., 2016. Rancang Bangun Sistem Rekomendasi Peminatan Fakultas Teknologi Informasi dan Komunikasi dengan Metode Analytical Hierarchy Process. Jurnal Buana Informatika, [ejournal] 7(2), p.151-158. Tersedia melalui: $<$ https://ojs.uajy.ac.id/index.php/jbi/article/ view/494/525> [Diakses 12 Januari 2018]

PRATAMA, D. \& HANSUN, S., 2017. Aplikasi Rekomendasi Tempat Makan Menggunakan Algoritma Slope One pada Platform Android. IJCCS (Indonesian J. Comput. Cybern. Syst.), [e-journal] 11(1), p.11-20. Tersedia melalui: <https://jurnal.ugm.ac.id/ijccs/article/view/ 15558/11718> [Diakses 10 Desember 2017]

SEKARAN, U., 2006. Metodologi Penelitian untuk Bisnis, Edisi 4. Jakarta: Salemba Empat.

SUMARLIN, E.W., HANSUN, S., \& WIRATAMA, Y.W., 2016. Rancang Bangun Aplikasi Rekomendasi Film dengan Menggunakan Algoritma Simple Additive Weighting. Jurnal Informatika, [e-journal] 10(2), p.1244-1250. Tersedia melalui: <http://journal.uad.ac.id/index.php/JIFO/art icle/view/5066/2829> [Diakses 12 Januari 2018] 
Jurnal Teknologi Informasi dan Ilmu Komputer (JTIIK)

DOI: $10.25126 /$ tiik.201851626

Vol. 5, No. 1, Maret 2018, hlm. 87-94

p-ISSN: 2355-7699

Akreditasi RISTEKDIKTI, No 48a/E/KPT/2017

e-ISSN: 2528-6579

Lampiran. Contoh kuesioner penelitian yang telah diisi oleh responden

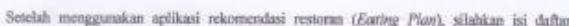

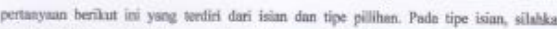
mengiai jouabon pude kolom yang disediakin, untuk tipe pilisun, silahkan diberi lingkaran

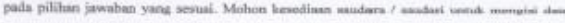
din yang telah disediakan terlebih detulu.

Nama : Wires

Umux

Pekerjan

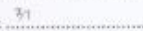

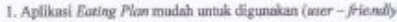

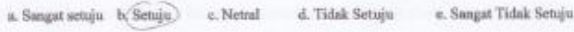

2. Aplikssi Earing Plan memiliki nuncangan maturnuka yang merarik,

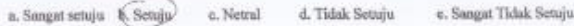

3. Eating Plan memberikan informasi restican secara lengkap

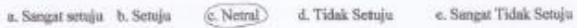

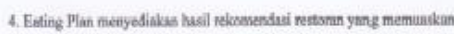

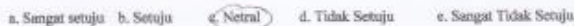

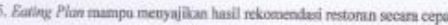

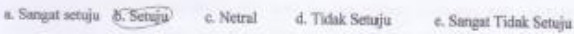

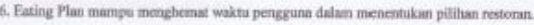

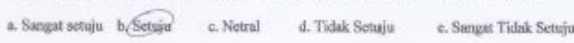

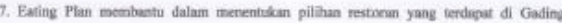

Serpong.

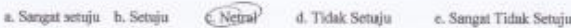

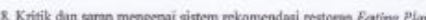

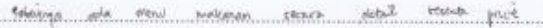

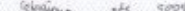

